\title{
Error Analysis of Language in Political Party Banner In Nagan Raya Regency, Aceh
}

\author{
Amnur Rifai Dewirsyah \\ Indonesian Language and Literature Education, University of Muhammadiyah Sumatera utara \\ Email: 140279rifai@gmail.com
}

\begin{abstract}
This study aims to describe the Indonesian language errors found in writing Political Party banners in Nagan Raya City. The approach used in this study is a theoretical and methodological approach. The theoretical approach in this study uses the Indonesian language error analysis approach, while the methodological approach used is a qualitative descriptive approach. Data collection was carried out using direct observation (observation), note-taking techniques, and documentation. Analysis of the data using split and replace techniques. Presentation of the results of data analysis using informal methods. The research design carried out is: (1) The initial stage is the preparation stage to identify problems and search for literature studies especially with reference to previous research journals, (2) after the problems have been identified and the basics of literature study are found, the next stage is conducting data collection with direct observation or observation, (3) After the data has been collected, recorded and documented, then analyzed using reference sources, (4) Evaluating to obtain new data as a basis for concluding the results of the study. The conclusion from the results of this study is that there are still many errors in Indonesian language in writing banners in Nagan Raya District that are not / not in accordance with the good and correct Indonesian language rules. Forms of writing errors on Political Party banners in Nagan Raya Regency. Includes writing errors of standard words and nonstandard words.
\end{abstract}

Keywords:language errors; standard; non-standard words

\section{Introduction}

Language is a symbolic system of speech which is used to communicate that is to express thoughts, feelings, desires to others. The use of language in every day human activity is the embodiment of language as a tool or medium of interaction between people. In its use there are often many errors both verbally and in writing that deviate from the rules of the language and are not in accordance with the Big Indonesian Dictionary (KBBI). The slogan "Use Indonesian language properly and correctly" the farm is easy to say, but the meaning is not clear. The slogan is just a rhetoric that is not tangible, because it still means that in all places we must use standard language. Likewise, there is still a scorn that the standard language is only made by the government so that this nation can be uniformed in acting or speaking.Language errors that occur in the community is a habit that has been inherited from generation to generation so that it is difficult to release and the lack of public insight into Indonesian that is good and right causes errors to occur frequently. Thus there were writings that were not in accordance with the good and true Indonesian language rules. Writing that is not in accordance with the KBBI can be found anywhere such as banners, announcements, 
billboards, and so on. These mistakes are often ignored, even often considered correct writing. Even though writings that are not in accordance with the KBBI must be immediately justified and do not leave it alone, because if left unchecked it will continue to be entrenched.For example, these errors can be found in writing banners. In writing banners there are still many that are not in accordance with the rules of the Indonesian language. Example:

\begin{tabular}{|l|l|}
\hline Baku & not Baku \\
\hline Child & Aneuk \\
\hline Insya Allah & InsaAllah \\
\hline Rakan & Rekan \\
\hline
\end{tabular}

Based on this background, the researcher was interested in researching "Language Error Analysis in Banners of Political Parties in Nagan Raya District".Problem identification is a stage to explain things related to the problem under study. The identification of the problem in this study is diction, spelling, sentence, standard word and non-standard word.The limitation of the problem of this research is that it is more focused and does not extend from the discussion of the problem in question, with this the researcher limits the problems of standard words and non-standard words.Formulation of the problem of word usage, with demands to follow the improved Indonesian grammar and spelling rules. It should be in accordance with the rules set by the Language Center. The formulation of the problem that will be discussed in this article is: the use of any word, which is found in many errors in the community? What are the non-standard words that are often used by people / students, wrong in writing or speaking? What are the punctuation marks, which are found in many places in the community? How do you put punctuation marks that are in accordance with the improved spelling? In a banner of a political party in Nagan Raya Regency ?.The aim of the study is to describe errors in the use of standard grammar and punctuation, by the community / students after the introduction of errors, identification, and classification of these errors. Hopefully with this writing, a little information, how to use standard language and punctuation which is in accordance with the improved Indonesian spelling rules. So that these mistakes are not repeated in every writing activity.The results of this study are expected to provide benefits practically. For the writer, get a data to complete the final project, namely data about analyzing the use of standard words and non-standard words, for the reader can be an additional knowledge in using standard words and non-standard words. learn to learn Indonesian about the use of standard words and non-standard words.

\section{Theoretical of Frame Work}

\subsection{Spelling}

Spelling is the phoneme symbolization with letters (Badudu, 1985: 31). In the spelling system of a language, it is determined how the phonemes in the language are symbolized. The phoneme symbol is called a letter. The arrangement of a number of letters in a language is called the alphabet.In addition to phoneme symbolization with letters, the spelling system includes 10 provisions on how morphological units such as basic words, repeated words, compound words, compound words and particles are written. provisions on how to write sentences and parts of sentences with the use of punctuation marks such as points, commas, semicolons, colons, quotation marks, question marks, exclamation points.Spelling is based on 
convention solely, so it is born out of the approval of the relevant language users. The spelling was prepared by a linguist or by a committee consisting of several linguists, then authorized or formalized by the government. The language user community obeys what has been established. The spelling we use today is the Enhanced Spelling, the spelling that has been compiled by the National Language Institute (LBN).

\subsection{Good and Right Indonesian Language}

The role of the main language is as a means of communication, as a means of conveying the intent and feeling of a person (communicator) to others (communicants). Addressed from this angle, someone's language is good if they are able to carry out the mandate. However, remembering that the linguistic situation is various, not always a good language is right, or vice versa, it is not always the right language is good. Likewise, in Indonesian, good Indonesian language is not always correct and correct Indonesian is not always good (Sloka, 2006: 112). Whereas according to (Hasan Alwi, 2010: 20). The use of language that follows the standardized or standardized rules is the correct language.Standard words are standard words in accordance with the rules of language that apply, based on the study of various sciences, including linguistics and in accordance with the times.

\subsection{Language Errors}

There are two opposing views regarding language errors. That is the view from the teacher's point of view and the perspective of the student. From the teacher's point of view, the mistake is a disgrace or blemish for language teaching. Language errors made by students indicate that language teaching is not successful or failed. Therefore, language errors must be avoided so that language teaching is successful. While from the point of view of students, language errors are an integral part of the language learning process. Mistakes can certainly be minimized or even eliminated by arranging more perfect components of the language teaching and learning process.

Then what will be the language error? To answer this question, according to Djago Tarigan (1997: 29) can be seen by referring to the slogan "Use good and right Indonesian." In the slogan, there are two measures that can be used as a basis. The first measure relates to the determinants of communication. Determining factors in communicating are: who speaks with whom, for what purpose, in what situation (place and time), in what context (other participants, culture, and atmosphere), with which pathway (verbal or written), media what (face to face, telephone, letters, books, newspapers, etc.), and in what event (conversations, lectures, ceremonies, reports, job applications, statements of love and so on) While the second measure relates to linguistic rules known as grammar.Thus Indonesian language is good and right is Indonesian which is in accordance with the determinants of communication and correct in the application of linguistic rules. The use of language that is not in accordance with the determinants of communication is not good Indonesian. Indonesian language that deviates from the rules of the language is also clearly not the correct Indonesian language. According to Tarigan (1997), language errors are considered as part of the teaching and learning process. Language error analysis work steps according to Ellis and Sridhar (in Tarigan, 1998) can be done through five steps.

1. Collect data 
2. Identifying errors

3. Classify errors

4. Explain the frequency of errors

5. Correct errors.

In more detail, the language error analysis method is carried out by collecting samples of errors made by students either in essays or other forms carefully and in detail. Language errors that have been collected are analyzed by the following steps: First, classify language errors based on linguistic levels such as phonological, morphological, syntactic, discourse or semantic errors. Second, sort the errors based on their frequency. Third, describe the location of the error and estimate the cause of the error. Fourth, estimate or predict areas or linguistic fault-prone areas. Fifth, correct errors or correct errors.In the study of theoretical framework according to a number of theories related to research problems to obtain theory must be guided by science namely by learning. Therefore, the theoretical framework is a theoretical design that relates to the nature of a study to explain the research of the variables studied.

According to Sugiono (2008: 79) is a set of constructs (concepts) definition, and propositions that function to systematically view phenomena, through the specification of relationships between variables, so that it can be useful to explain and predict phenomena.

Theory is a supporting factor in a study. Both qualitative and quantitative research. Theory is an opinion based on research and findings supported by argumentation data. Theoretical studies in a study are a series of theories related to the problems contained in the study. These theories will greatly assist research in answering the problems contained in a study.

\section{Good and Right Indonesian Language}

The correct Indonesian language is Indonesian which is used in accordance with the rules or rules of the Indonesian language in force. The Indonesian rules include spelling rules, word formation rules, sentence preparation rules, paragraph preparation rules, and reasoning structuring rules. If spelling is used carefully, the rules of word formation are carefully observed, and the arrangement of reasoning is obeyed consistently, the use of Indonesian is said to be true. Conversely, if the language rules are not adhered to, the use of the language is considered incorrect.Indonesian language that is good and true is the Indonesian language that is used in accordance with the prevailing social norms and in accordance with the applicable Indonesian language rules. The use of regional pronunciation, such as the pronunciation of Javanese, Sundanese, Balinese, Acehnese and Batak in Indonesian in official situations should be reduced.Based on the above understanding, it can be concluded that a good Indonesian language is in Indonesian language that corresponds to the place where language contact occurs, according to who the person is talking to, and in accordance with the topic of conversation. Good Indonesian language does not always need a variety of standards. What needs to be considered in a good Indonesian language is the use of appropriate and harmonious variety according to the class of speakers and the type of language usage. 


\section{Language Error Analysis}

Atar (990: 32) language errors are the use of language both orally and in writing which deviate from the determinants of communication or deviate from social norms and deviate from Indonesian grammar rules.Language errors are the use of unwanted speech forms. Language errors can occur due to the ability to understand the community. This means that people do not understand the language system used. Errors usually occur systematically. The mistake that often occurs is that the standardization of the word has not been socialized in the community. Thus, the community does not know which standard word and which word is not standard. People often do not have the opportunity to see the standard rules. They often hear people talk, or read writings in magazines or other print media. Meanwhile, those who speak or who write also of course use things that are standard.This type of error can last a long time if it is not repaired. The repair is usually done slowly. For example, training, practice, etc. to the community. Sometimes it is often said that mistakes are a description of people's understanding of the language system being used. If the stage of community understanding of the language system being learned turns out to be lacking, errors will often occur. Errors will decrease if the understanding stage gets better.Based on this understanding it can be concluded that language errors are the use of speech forms that are not in accordance with the Indonesian language rules or that balance the Indonesian social norms and grammar that have been established both orally and in writing.

\section{The word Baku and the word Not Baku}

The standard word is a word that is used in accordance with the guidelines or rules of the language that have been determined or the standard word is the correct word with the rules and spelling of the Indonesian language rules and the main source of the standard language is the Large Indonesian Language Dictionary (KBBI), the standard word generally often used in official sentences, both in writing and in expressing words.Chaer (2000: 6) suggests that the standard word is the words used are common words that are commonly used or the frequency of use is quite high. Furthermore Nababan (2008: 44) argues that the standard word is words that are the way of pronunciation and writing in accordance with the prevailing Indonesian language rules.From the expert's opinion, it can be concluded that the standard words are words whose pronunciation and writing are commonly used and have been established in the Indonesian language rules which become the benchmark for Indonesian language users.

The default word function is as follows:

1. Unifying, the use of standard language can unite a group of people into a unity.

2. Giving sincerity, the use of standard language can be a differentiator from other languageuse communities.

3. Carrier authority, the use of standard language can show the authority of the wearer.

4. Terms of reference, standard language is the benchmark for the correctness or failure of the language usage of a person or group of people.

The characteristics of the raw words: 
1) Not influenced by regional languages.

In everyday conversation, usually we will tend to use a variety of languages that correspond to the habits in our area. The standard word is not influenced by regional languages such as the addition of a suffix to a word, a specific term or designation, or a word prefix.

Example:

\begin{tabular}{|l|l|}
\hline standard & Not standard \\
\hline$I$ & I \\
\hline Meet & Find it \\
\hline Feel & Feel \\
\hline
\end{tabular}

2) Not influenced by foreign languages.

Variety of standard languages is not influenced by foreign languages. If there is a foreign language influence such as the addition of help words, exchange of positions, differences in meaning and so on, then the language is a non-standard language.

Example:

\begin{tabular}{|l|l|}
\hline standard & Not standard \\
\hline That is wrong & That is wrong \\
\hline Another chance & Another chance \\
\hline The place & Where \\
\hline
\end{tabular}

3) Not the language of conversation

The variety of languages used in everyday conversation is generally non-standard language or market language. the standard word is not a conversation language and sounds more formal or official.

Example:

\begin{tabular}{|l|l|}
\hline standard & Not standard \\
\hline But & But \\
\hline No & No \\
\hline How & How about \\
\hline
\end{tabular}

4) Using explicit additions

The variety of standard languages uses affixes (prefixes, inserts, and endings) clearly so that the meaning of the meaning is clear. The use of affix explicitly shows the true meaning so that the sentence is easy to understand.

Example:

\begin{tabular}{|l|l|}
\hline standard & Not standard \\
\hline Sing & Sing \\
\hline Play & Play \\
\hline
\end{tabular}

5) Use according to the context of the sentence 
The use of a variety of standard languages in accordance with the context of the sentence so that more appropriate sentences are produced. If using a non-standard word, the sentence will feel less precise.

Example:

\begin{tabular}{|l|l|}
\hline standard & Not standard \\
\hline Of the & From \\
\hline caused by & Due \\
\hline
\end{tabular}

6) Not contaminated and not ambiguous

This point is one of the characteristics of standard language that tends to be difficult to understand because confusion is relative and is strongly influenced by habits. the standard word does not contain double meaning so it is more effective.

Example:

\begin{tabular}{|l|l|}
\hline standard & Not standard \\
\hline Saving time & Shorten the time \\
\hline Get & Get \\
\hline
\end{tabular}

7) Does not mean pleonasm

Pleonasme is a majas that uses a word or information which is actually no longer needed because the meaning of the word is the same as the word it describes. In other words, the addition of an adverb to the statement that has a clear meaning.

Example:

\begin{tabular}{|l|l|}
\hline standard & Not standard \\
\hline Advanced & Come forward \\
\hline Go up & Going up \\
\hline Audience & Audience \\
\hline
\end{tabular}

\section{8) Does not mean hypercoritus}

Hiperkorek is a language error due to excessive correction of the correct form causing errors. Hiperkorek is demanding neatness and perfection that is so excessive that the results actually become less precise.

Example:

\begin{tabular}{|l|l|}
\hline standard & Not standard \\
\hline Insaf & Realize \\
\hline Thank you & Thank you \\
\hline Legitimate & Shah \\
\hline
\end{tabular}

The standard words are words that are used in accordance with the rules of the Indonesian language that have been predetermined and a word can be called the word nonstandard if the word used is not in accordance with the Indonesian language rules. The nonstandard of a word is not only caused by the wrong writers, but can also be caused by 
incorrect pronunciation and the preparation of an incorrect sentence usually non-standard words always appear in our daily conversation. The word non-standard is the word used not in accordance with the guidelines or rules of the language that have been determined. Usually the word non-standard is often used during everyday conversation or in speech. The factors that can lead to the emergence of words are not standard, which includes the following:

a. Those who use language do not know the form of writing from the word he meant.

b. Those who use language do not correct errors from the use of a word, which is why the standard word always exists.

c. Those who use language can be affected by people who are accustomed to using nonstandard words.

d. Those who use language can be used to using non-standard words.

\section{Definition of Banners}

In the science of advertising, there are various kinds of promotional media such as leaflets, banners, banners, posters, and many more, each promotional media has its own form and function. The banner is a range of cloth containing propoganda, slogans or news what the public needs to know. The banner is also a stretched cloth which is usually also on the edge of the road that contains a text, colored and pictorial. Banners of information media, banners we usually make ourselves, can use paint, screen printing (screen printing) or digital print.

Banners are needed because it is a promotional medium to be able to introduce or to make the general public aware of information. By using a banner you can display an image and at the same time an information that can support people's interest.Banners in political parties are seen as an effective medium to convey the vision and mission of candidates for political parties, so that the language chosen is a suggestion with a message so that the community is interested in what they convey. Using public banners can see pictures of candidates for political parties directly.From this explanation it can be concluded that the banner is an information medium introducing to the general public to find out information in the form of slogans or news, which is a stretched cloth and is usually located on the edge of the road containing writing, discourse and images.

\section{Banner language}

The language used in banners is a language that builds emotions and forms imagination so that it influences the reader to act as expected by the text maker. The power of this influence is so strong, even as hypnotic. Therefore the language in the banner is demanded to be able to attract the attention of those who read it.Language is an important tool for communication in banners and supported by interesting images, so the banner is said to be able to steal the attention of the audience. Language requirements in banners are:

a. Banners must use language that is easy to understand.

b. The composition of the sentences should be short, solid, clear, but contained.

c. Banners should be combined with image shapes.

d. Banners must be able to attract audiences. 
This banner is suitable for use in political media, through banners politicians can make themselves or their political parties to society by using slogans that are interesting and easily understood by the public.

\section{Conceptual Framework}

The conceptual framework is a research series used in directing the way of thinking in order to find the right problem. Researchers set the framework as a basis for research problems. banners are information media introducing to the general public to find out information in the form of slogans or news, which is a stretched cloth and usually located on the edge of the road that contains writing, discourse and images.Language errors occur due to a lack of public insight into good and right languages. Speaking of language errors in the banner of political parties in Nagan Rayaerror Regency contained in the banner is about the standard words and non-standard words. Standard words are words whose pronunciation and writing are commonly used and have been defined in the Indonesian language rules which become the benchmark for Indonesian language users. The word non-standard is the word used not in accordance with the guidelines or rules of the language that have been determined. Usually the word non-standard is often used during everyday conversation or in speech.

\subsection{Research Statement}

This research is a research with qualitative descriptive method so that it does not use research hypotheses. Based on the theoretical framework and the conceptual framework above, the research statement is "There were language errors found in the banner of political parties in Nagan Raya District".

\section{Method of The Research}

\subsection{Research Design}

The research design that is planned in outline can be described as follows.

i. The initial stage is the preparation stage to identify problems and search for library studies with reference to previous research journals. This is useful for knowing the problems to be studied.

ii. After the problem is identified and the basics of literature study are found, the next stage begins to collect data by direct observation through observation and documentation. The object observed was writing on banners in Nagan Raya Regency, which included billboards, and banners.

iii. After collecting the necessary data, the data is processed and used as the basis for the implementation of the research.

iv. The next step is the implementation of activities that support the research.The activities carried out were identifying Indonesian language errors in writing outside 
media in the Nagan Raya District area, through forms of error, and continued to classify errors in Indonesian.

v. The final step is to evaluate the results of the identifiers and classifications to get the final conclusions.

vi. During the study discussions were always held with senior researchers to maintain the quality of research results.

The following is a description of the research design that will be carried out by researchers.
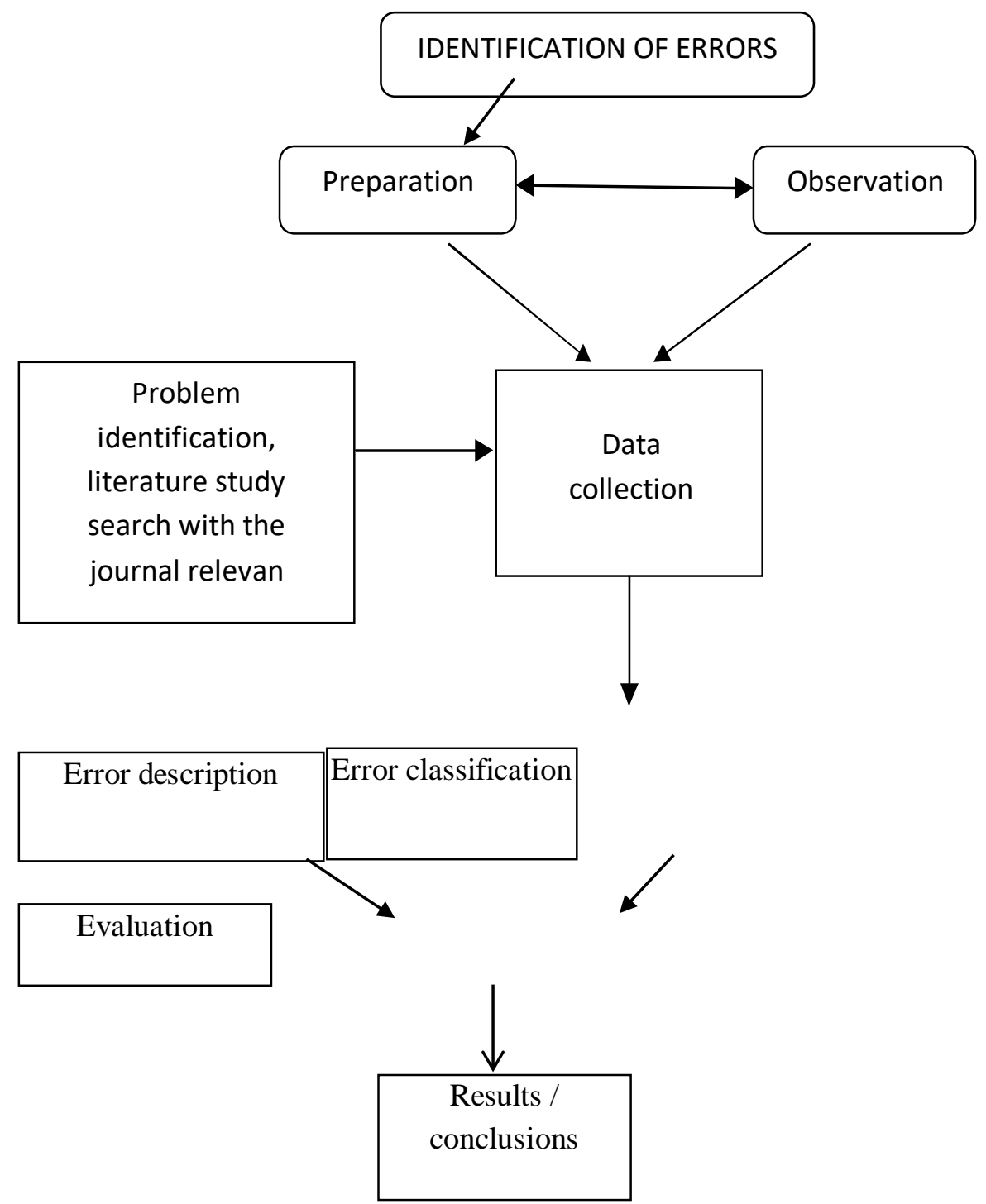

Figure 1. Design of Research Implementation

\subsection{Research Methodology}

The method used in this research is the descriptive method and descriptive technique. See method is the method used to obtain data by listening to the use of language. The term listening is not only related to the use of language orally, but also the use of the language in writing.The analytical technique used in this study is a qualitative descriptive-prescriptive 
technique, namely by describing and explaining the findings in the field and providing solutions or solutions to the problems contained in the use

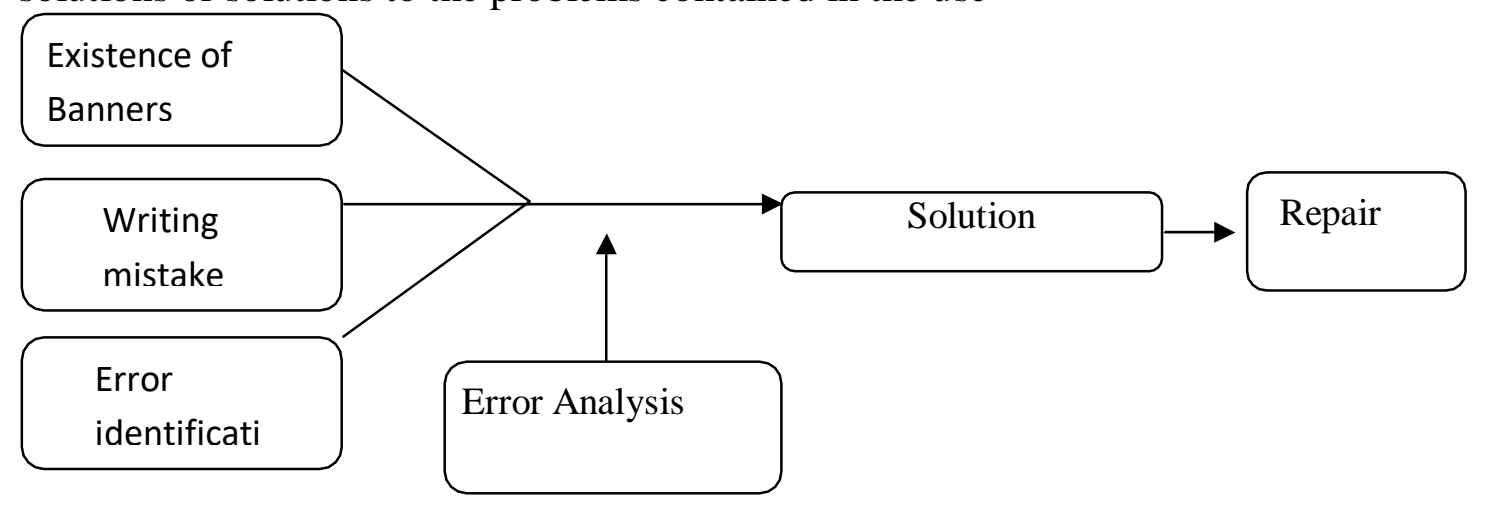

Indonesian language on a banner of a political party that is in the territory of Nagan Raya Regency.This research will be carried out in the area of Nagan Rayad Regency by using outdoor advertising media, such as banners and billboards in the city of Langsa as the object of research. The following is a description of the research methodology that will be planned

\subsection{Techniques of AnalysisData}

Data analysis is systematic for records or data as a source of problems. Although the power usually contains written or printed sentences, but the data is actually unlimited, it can be in the form of graphics, pictures, paintings, photos, and so on. The technique used in this study is a type of qualitative technique. Satoto (1995: 15) said that qualitative analysis can be classified into descriptive methods whose application is said, explained, provided, analyzed and interpreted.

The steps that the author did in analyzing the data are as follows:

1. Understand the contents of political party banners.

2. Identifying language errors found in political party banners.

3. Record the data that has been identified.

4. Describe the data to obtain the formulation of results that are in accordance with the research objectives.

\section{Results And Discussion Research}

In this chapter, the data that has been collected is analyzed based on a predetermined method. The data obtained in this study is a non-standard word in a political party banner in Nagan Raya Regency, which is presented as follows:

Table 1.Word Data Is Not Raw

\begin{tabular}{|c|c|}
\hline No & Said No standard \\
\hline 1 & Aneuk \\
\hline 2 & Rakan \\
\hline 3 & InsyaAllah \\
\hline 4 & Perekat \\
\hline 5 & Do'a \\
\hline
\end{tabular}




\begin{tabular}{|c|c|}
\hline 6 & Atjeh \\
\hline 7 & Kwe \\
\hline 8 & For you \\
\hline 9 & Let us succeed \\
\hline
\end{tabular}

\subsection{Data Analysis}

Based on the description of the data can be explained about the non-standard words in the banner of political parties in Nagan Raya Regency.

1. Aneuk said

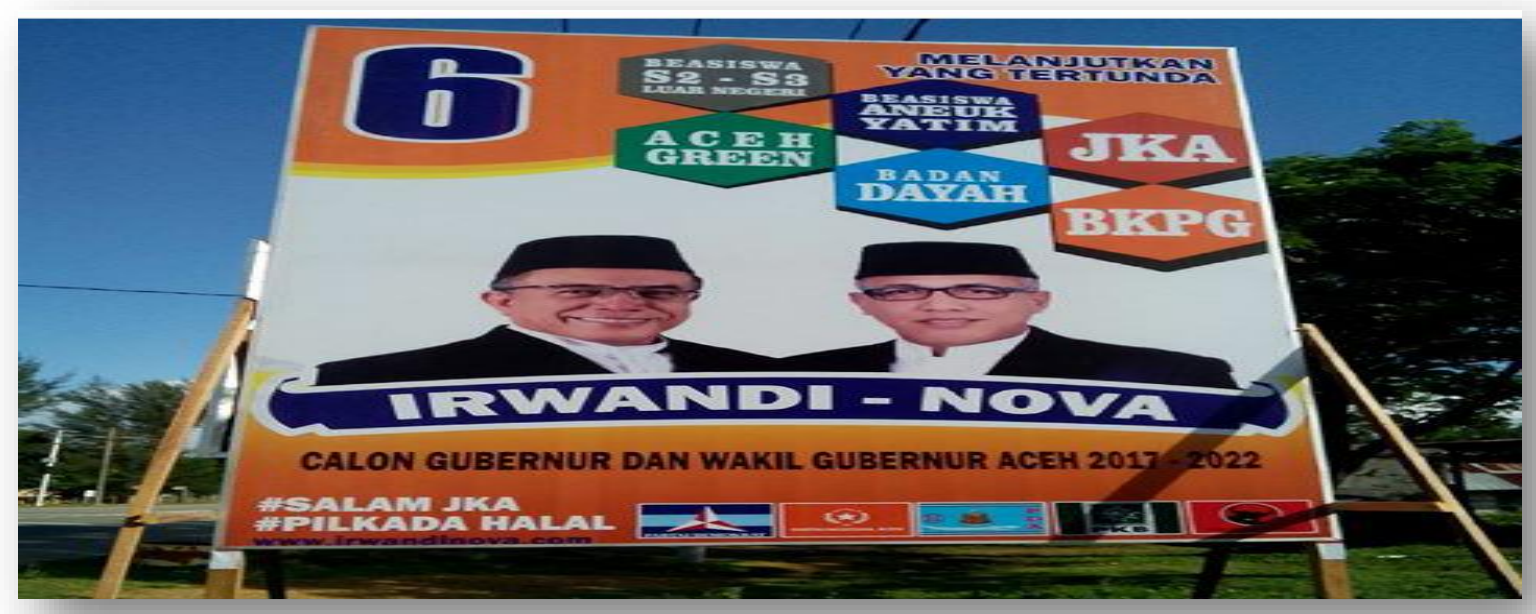

The word aneuk in the banner of the political party is a non-standard word because the election of the governor and deputy governor is official. So the word used must be in accordance with the Indonesian language rules and the Great Indonesian Dictionary, the word aneuk in Indonesian is a child in accordance with the Indonesian rules and the third edition of the Great Indonesian Dictionary issued by the Ministry of National Education and Library.

2. Rakan

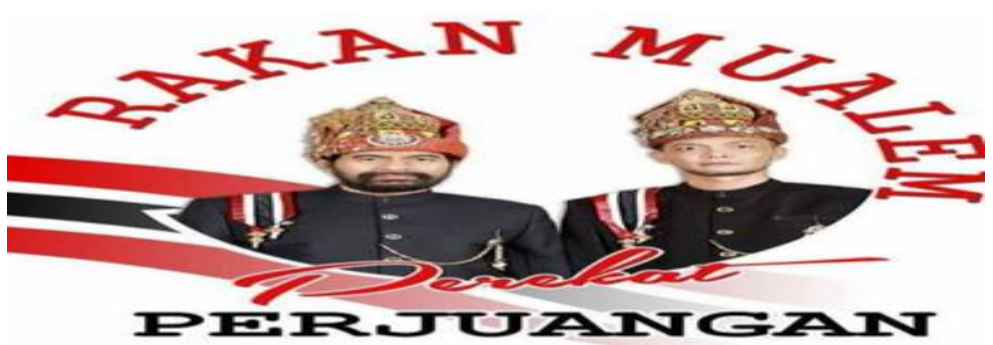

The word friend in the banner of the political party is a non-standard word because the election of the governor and deputy governor is official. So the word used must be in accordance with the Indonesian rules and the Great Indonesian Dictionary, the Indonesian 
word for companion is in accordance with the Indonesian language rules and the third edition of the Large Indonesian Dictionary issued by the Ministry of National Education and Library

\section{Insya Allah}

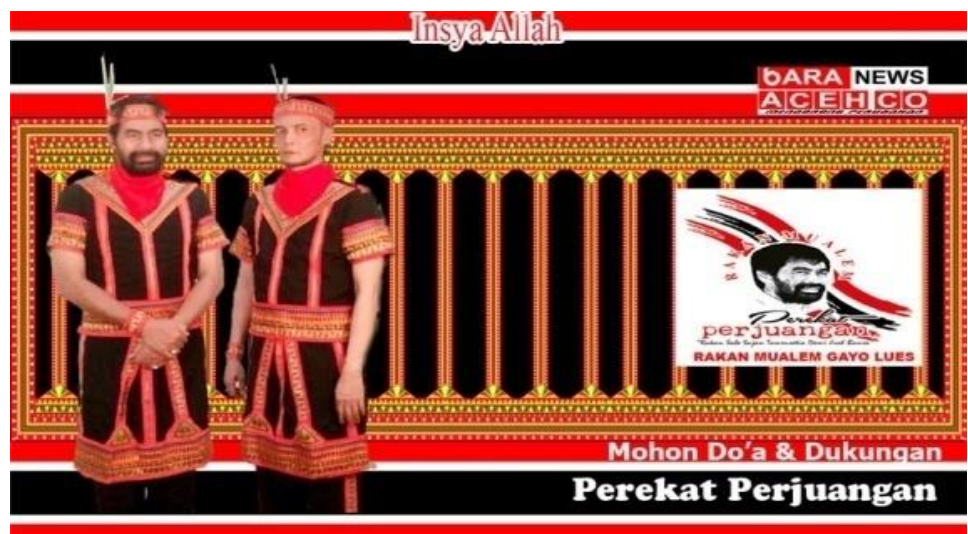

The word Insya Allah in the banner of the political party is a non-standard word, because it is not in accordance with the rules of the Indonesian language and the Big Indonesian Dictionary. Insya Allah in Indonesian is not written in series, the writing InsyaAllah in Indonesian is Insya Allah in accordance with the rules of the Indonesian language and the third edition of the Indonesian Large Dictionary issued by the Ministry of National Education and Library.

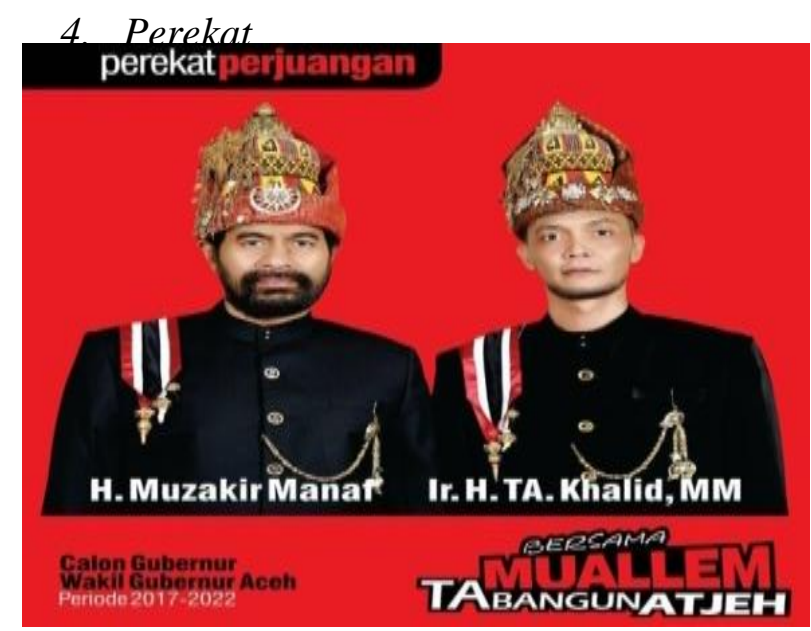

The word glue in the political party banner is a non-standard word because the election of the governor and deputy governor is official. So the word used must be in accordance with the Indonesian language rules and the Indonesian Big Dictionary, the word adhesive in Indonesian is a blessing in accordance with the Indonesian language rules and the third edition of the Great Indonesian Dictionary issued by the Ministry of National Education and Library.

5. Do'a 


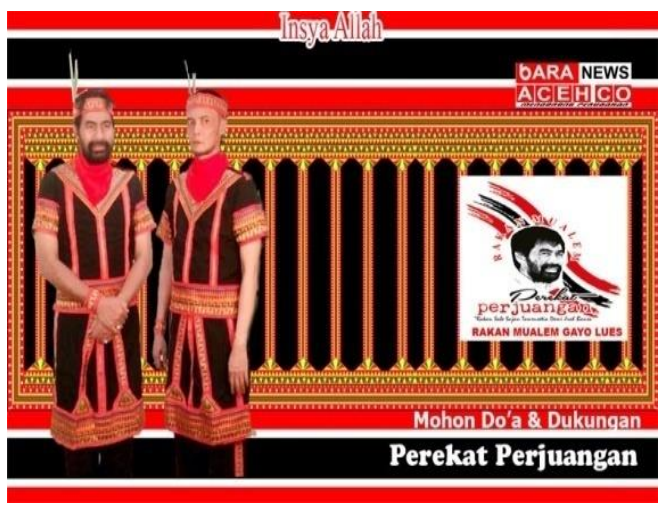

The word prayer in the banner of the political party is a non-standard word because it is not in accordance with the Indonesian rules and the Big Indonesian Dictionary. The word prayer in Indonesian is not written using the comma above, the word prayer in Indonesian is a prayer that is in accordance with the Indonesian language rules and the Big Indonesian Dictionary of the third edition issued by the Ministry of National Education and Library.

\section{Atjeh}

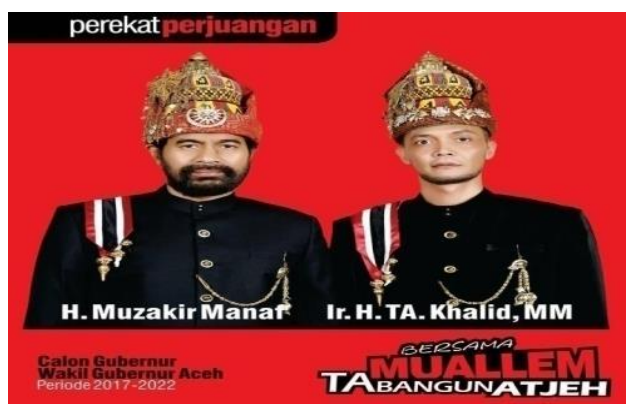

The word atjeh in the banner of the political party is a non-standard word because the election of the governor and deputy governor is official. So the word used must be in accordance with the Indonesian language rules and the Great Indonesian Dictionary, the word atjeh in Indonesian is Aceh in accordance with the Indonesian rules and the third edition of the Great Indonesian Dictionary issued by the Ministry of National Education and Library.

7. Kwe

8.

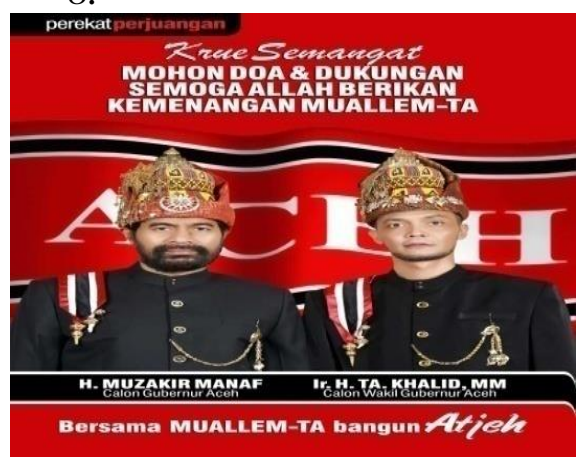

The word kwe in the banner of the political party is a non-standard word because the election of the governor and deputy governor is official. So the word used must be in accordance with the Indonesian rules and the Great Indonesian Dictionary, the word kwe in 
Indonesian is fixed in accordance with the Indonesian rules and the third edition of the Large Indonesian Dictionary issued by the Ministry of National Education and Library.

9. For you

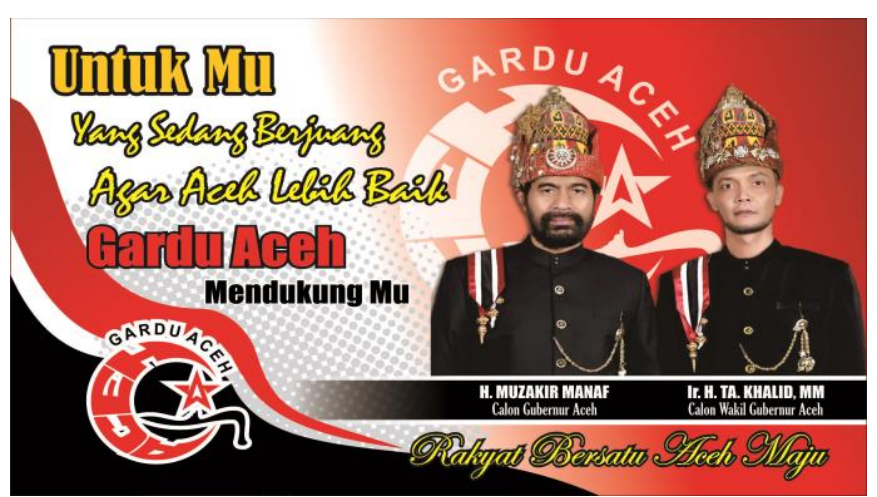

According to the book Analysis of Language Errors (Theory and Metology) of Dr. Charles Butar-Butar, M.Pd, the sentence is not an effective sentence, an effective sentence must use accuracy in taking part, he said, what is meant by accuracy is that the sentence does not cause multiple interpretations and is appropriate in the choice of words. Accuracy in sentences is related to word selection, word compilation, and the use of logic in sentences. The sentence for you, the choice of the word is not right because you intended it for one person only. While there are two pictures in the banner so the selection of the words is not right, then you can replace your word with you.

\section{Let us succeed}

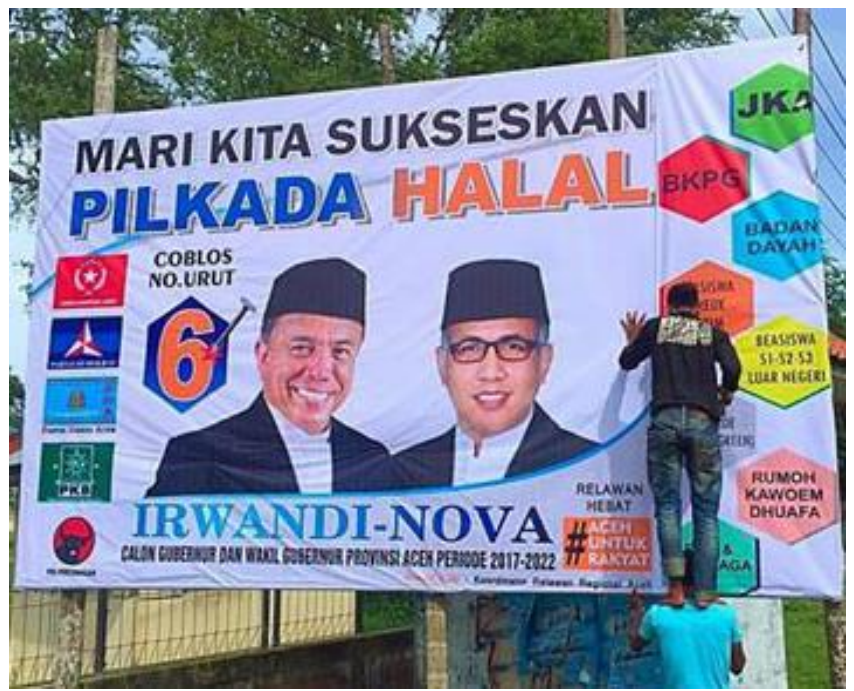

According to the book Analysis of Language Errors (Theory and Metology) of Dr. Charles Butar-Butar. M, In the sentence it is not an effective sentence, the effective sentence must have coherence in taking it, he said, what is meant by cohesion is the cohesion of the statement in the sentence so that the information conveyed is not fragmented. A solid sentence is not long-winded and does not reflect an unsystematic way of thinking. A coherent sentence does not need to insert a word between work prediction and object. The sentence let's succeed 
is not a coherent sentence because it inserts a word between prediction and object, then the right sentence is let's succeed.

\subsection{Answers to Research Questions}

Based on the results of the study, there are non-standard words in the banner of political parties in Nagan Rayater, there are 9 non-standard words, namely aneuk, rakan, InsyaAllah, adhesive words, prayer words, atjeh words, kwe words, words for you, and words let's succeed.

\section{Conclusions}

Based on data analysis and research results that have been carried out in chapter IV, it can be concluded that the non-standard words in the banner of political parties in Nagan Rayab Regency are nine data, which consists of aneuk, the words of friends, the word Insya Allah, the word adhesive, the word prayer, the word atjeh, the word kwe, the word for you, and the word let's succeed.Errors in Indonesian language were found at most in the application of enhanced Indonesian spelling rules. With the existence of Law Number 24 of 2009 which regulates the use of flags, Languages and national symbols, and national anthems.

\section{References}

Arikunto, Suharsini.2009.Metode Peneitian Kualtatif dan Kuantitatif. Jakrata: Rineka Cipta.

Butar-Butar,2016.Charles.Analisis Kesalahan Berbahasa(Teori dan Metodologi) Diktat (edisi revisi).

Chear, Abdu.2000.Tata Praktis Bahasa Indonesia.Jakarta:Rinika Cipta

Chaer, Abdul. 2009. Pengantar Semantik Bahasa Indonesia. Jakarta: Rineka Cipta.

Kamus Besar Bahasa Indonesia. Edisi ketiga. Depertemen Pendidikan Nasional dan Balai Pustaka

Nababan, Diana.2008.Intisari Bahasa Indonesia untuk SMA.Jakarta:Kawan Pustaka. Satoto, Jos Danil.1993.Metologi Penelitian Sastra II.Surakarta:UNS Press.

Semi, Atar M.1190.Menulis Efektif.Padang:Angkasa Raya Padang.

Siswantoro.2005.Metode Penelitian Sastra, Analisis Stuktur Puisi.Pustaka Pelajar.

Sugiono 2008. Metode penelitian pendidikan kuantitatif, kualitatif, dan R\&D.

Bandung:Alfabeta.

Sutopo, H.B. 2002. Metologi Penelitian Kualitatif. Surakarta:UNI Press. 